\title{
Analisis Potensi Jiwa Kewirausahaan Siswa Sekolah Menegah Kejuruan
} Faramita Paputungan', Sitti Roskina Mas ${ }^{2}$

\author{
1'2'Jurusan Manajemen Pendidikan Fakultas Ilmu Pendidikan, Universitas Negeri Gorontalo
}

E-mail: paputunganfaramita@gmail.com

\begin{tabular}{l} 
Info Artikel \\
\hline Sejarah Artikel: \\
Diterima: Agustus 2021 \\
Disetujui: September 2021 \\
Dipublikasikan: September \\
2021
\end{tabular}

\section{Kata kunci}

Kewirausahaan; Kepribadian;Disiplin; Kreativitas;Motivasi; Keberanian; Kepercayaan Diri

\section{Keywords:}

Entrepreneurship; Personality;Discipline; Creativity;Motivation; Bravery; Confidence

\begin{abstract}
ABSTRAK
Penelitian ini bertujuan untuk mengetahui potensi jiwa kewirausahaan siswa SMK dilihat dari aspek: (1) kepribadian; (2) disiplin diri; (3) kreativitas; (4) motivasi; (5) keberanian; (6) kepercayaan diri. Penelitian ini menggunakan metode kuantitatif dengan jenis pendekatan eksplanatori. Jumlah subjek penelitian sebesar 32 orang. Teknik pengumpulan data menggunakan angket, wawancara, observasi, dan dokumentasi. Teknik analisis data yang digunakan adalah teknik analisis deskriptif dengan menggunakan formula persentase. Hasil Penelitian ini menunjukkan bahwa potensi jiwa kewirausahaan siswa SMK Negeri 1 Posigadan Kabupaten Bolaang Mongondow Selatan dilihat dari aspek: (1) kepribadian berada pada kategori cukup baik dengan persentase sebesar 74,50\%; (2) disiplin diri berada pada kategori cukup baik dengan persentase sebesar 74,00\%; (3) kreativitas berada pada kategori cukup baik dengan persentase sebesar 72,25\%; (4) motivasi berada pada kategori cukup baik dengan persentase sebesar 71,25\%; (5) keberanian berada pada kategori cukup baik dengan persentase sebesar $72,38 \%$; (6) kepercayaan diri berada pada kategori cukup baik dengan persentase sebesar 73,63\%. Untuk itu disarankan: (1) Bagi Sekolah, hendaknya untuk dapat meningkatkan profesionalisme guru dan menyelenggarakan berbagai kegiatan seperti bazar sekolah, workshop siswa dan menghadirkan tokoh-tokoh wirausahawan sukses untuk dapat memberi wawasan dan pengalaman terhadap para peserta didik; (2) Bagi Guru, diharapkan untuk dapat mengembangkan potensi jiwa kewirausahan melalui pembelajaran yang berisi kegiatan-kegiatan yang bersentuhan langsung dengan dunia usaha agar para peserta didik memiliki pengalaman secara nyata; (3) Bagi Peserta didik, hendaknya untuk selalu berkonsentrasi dan bersunguh-sungguh serta proaktif dalam menerima materi pendidikan kewirausahaan yang diberikan oleh guru.
\end{abstract}

\section{ABSTRACT}

This study aims to determine the potential of the entrepreneurial spirit of SMK students in terms of: (1) personality; (2) self-discipline; (3) creativity; (4) motivation; (5) courage; (6) self-confidence. This study uses a quantitative method with an explanatory approach. The number of research subjects was 32 people. Data collection techniques using questionnaires, interviews, observations, and documentation. The data analysis technique used is descriptive analysis technique using the percentage formula. The results of this study indicate that the entrepreneurial potential of students at SMK Negeri 1 Posiga and South Bolaang Mongondow Regency is seen from the aspects: (1) personality is in the fairly good category with a percentage of $74.50 \%$; (2) self-discipline is in the good enough category with a percentage of $74.00 \%$; (3) creativity is in the fairly good category with a percentage of $72.25 \%$; (4) motivation is in the good enough category with a percentage of $71.25 \%$; (5) courage is in the good enough category with a percentage of $72.38 \%$; (6) self-confidence is in the good enough category with a percentage of $73.63 \%$. For this reason, it is recommended: (1) For schools, they 
should be able to improve the professionalism of teachers and organize various activities such as school bazaars, student workshops and presenting successful entrepreneur figures to be able to provide insight and experience to students; (2) For teachers, it is expected to be able to develop the potential of the entrepreneurial spirit through learning that contains activities that are in direct contact with the business world so that students have real experience; (3) For students, they should always concentrate and be serious and proactive in receiving entrepreneurship education materials provided by the teacher.

(C) 2021 Faramita Paputungan, Sitti Roskina Mas

Under The License CC-BY SA 4.0

\section{PENDAHULUAN}

Sekolah Menengah Kejuruan merupakan salah satu lembaga pendidikan yang banyak melahirkan wirausahawan-wirausahan muda yang berkarakter dan berjiwa entrepreneur. Pendidikan kewirausahaan yang di ajarkan di Sekolah Menengah Kejuruan memberikan pengetahuan bagi siswa dan siswi dalam mengembangkan inovasi dan kreativitas kewirausahaan dan tidak hanya itu, pendidikan kewirausahaan dapat melatih siswa dalam melihat peluang usaha yang ada. Maka dari itu, pengembangan kewirausahaan di Sekolah Menengah Kejuruan dapat mengaktualisasikan potensi diri siswa dan siswi secara maksimal dalam menjalankan usaha secara mandiri setelah mereka lulus nanti.

Pendidikan kewirausahaan pada sekolah menengah kejuruan dapat dijadikan sebagai salah satu alternatif dalam mengatasi permasalahan ketenagakerjaan yang selama ini menjadi persoalaan yang tak kunjung selesai. Melalui pendidikan kewirausahaan para generasi muda dibekali dengan berbagai macam kompetensi yang diarahkan untuk mempersiapkan siswa dan siswi agar siap kerja dan mampu menciptakan lapangan kerja, dengan hal tersebut maka permaslahan pengangguran, dan kemiskinan dapat di atasi. Sebagaimana Peraturan Pemerintah Nomor 19 tahun 2005, pasal 26 ayat 3 bahwa standar kompetensi lulusan pada satuan pendidikan menengah kejuruan bertujuan untuk meningkatkan kecerdasan, pengetahuan, kepribadian, akhlak mulia, serta keterampilan untuk hidup mandiri dan mengikuti pendidikan lebih lanjut sesuai dengan kejuruannya.

Terkait analisis potensi jiwa kewirausahaan siswa peneliti mengambil lokasi di Sekolah Menengah Kejuruan (SMK) Negeri 1 Posigadan Kabupaten Bolaang Mongondow Selatan, dimana SMK tersebut telah memasukkan kewirausahaan sebagai mata pelajaran yang wajib bagi peserta didik untuk menumbuhkan keinginan untuk berwirausaha dan juga menggali potensi jiwa kewirausahaan para peserta didik. Selain itu mata pelajaran kewirausahaan yang 
diterapkan pada jenjang SMK Negeri 1 Posigadan Kabupaten Bolaang Mongondow Selatan bertujuan untuk membentuk pribadi peserta didik memilki jiwa entrepenur dan berkarakter, disertai dengan tingkat pemahaman dan ketrampilan sebagai wirausaha. Dengan mengajarkan peserta didik pengetahuan tentang wirausaha dapat meningkatkan jumlah para wirausaha yang memilki kualitas, handal, unggul dan mampu bersaing secara sehat dalam dunia usaha dan dunia industri.

Namun pada kenyataanya masih banyak lulusan-lulusan SMK yang menjadi pengangguran dan tidak tertampung dalam dunia kerja dan dunia industri. Hal ini sejalan dengan data Badan Pusat Statistik (2019) bahwa tingkat pengangguran di Indonesia berdasarkan jenjang pendidikan, didominasi oleh lulusan SMK yakni 8,63\%, lulusan diploma I/II/III sebesar 6,89\%, lulusan SMA 6,78\%, lulusan universitas 6,24\%, lulusan SMP 5,04\%, dan lulusan SD sebesar 2,65\%. Tingginya tingkat pengangguran lulusan SMK tersebut dipicu oleh tidak berimbangnya jumlah angkatan kerja SMK dengan jumlah serapan tenaga kerja di instansi maupun dunia industri dan dunia usaha. Sementara itu sebagian besar siswa SMK juga tidak mampu beradaptasi dan tidak mampu bekerja saat mereka melaksanakan praktek kerja lapangan dan tentunya hal tersebut berdampak pada saat siswa tersebut lulus nanti ia tidak mampu terjun ke lapangan kerja dan akhirnya jumlah pengangguran semakin bertambah dan kemiskinanpun merajalela.

Untuk mengatasi masalah tersebut pemerintah melakukan evaluasi pendidikan kewirausaan pada pendidikan formal melalui Instruksi Presiden No 9 Tahun 2016 tentang Revitalisasi Sekolah Menengah Kejuruan (SMK) dalam rangka peningkatan Sumber Daya Manusia (SDM) Indonesia. Pendidikan formal atau SMK berupaya mampu mengubah pola pikir lulusan SMK yang tidak hanya menjadi lulusan siap kerja namun menjadi lulusan siap berwirausaha dan mandiri akan tetapi juga memilki karakter yang kuat. Selain itu untuk mewujudkan pendidikan kewirausahaan yang optimal maka perlu di tunjang kompetensi yang dimilki oleh kepala sekolah dalam memaksimalkan tenaga pengajar.

Selanjutnya Roskina (2017) menjelaskan bahwa jiwa kewirausahaan seseorang dapat tumbuh apabila ia percaya diri dalam memunculkan gagasan pemikiran mengenai konsep yang muktakhir dalam mengembangkan usaha yang dijalankan. Selain itu dalam prosesnya kewirausahaan mencakup kegiatan yang berkaitan dengan prospek usaha dan menciptakan organisasi usaha yang menghasilkan profit atau keuntungan yang besar bagi wirausahaan. Dengan kata lain kepercayaan diri merupakan faktor penting dalam menumbuhkan jiwa 
kewirausahaan para siswa, sebab melalui kepercayaan diri dapat memunculkan keberanian dan motivasi bagi siswa untuk mau berwirausaha.

Lebih lanjut Dhanupoyo dan Roskina (2015) menyatakan bahwa dalam upaya pembinaan kompetensi kewirausahaan siswa SMK harus di arahkan pada nilai-nilai kewirausahaan yang diantaranya adalah: (1) kemandirian; (2) kreatif; (3) berani mengambil resiko; (4) berorientasi pada tindakan; (5) kepemimpinan; (5) kerja keras. Melalui ke 5 nilai tersebut siswa dapat meningkatkan kemampuan mereka dalam berwirausaha dan dengan modal kemampuan berwirausaha, pada saat lulus nanti para siswa tidak akan kesulitan dalam bekerja bahkan dapat membuka lapangan pekerjaan baru bagi masyarakat luas.

Berkaitan dengan potensi jiwa kewirausahaan siswa di sekolah maka proses pembelajaran yang dapat dilakukan oleh sekolah dengan melakukan proses pembelajaran yang mengarah pada proses produksi, dimana para siswa diajarkan untuk menghasilkan barang atau jasa yang tentunya memilki manfaat dan keuntungan/profit yang bernilai ekonomis. Kegitan tersebut dapat meningkatkan potensi jiwa kewirausahaan siswa secara maksimal, sekaligus melahirkan entrepreneur- entrepreneur muda yang berkompeten (Sutianah, 2020).

Riset yang dilakukan oleh Lukman (2015) meunjukan bahwa salah satu pengembangan potensi jiwa kewirausahaan siswa dilakukan melalui pengelolaan business center. Melalui kegiatan tersebut para siswa di ajarakan bagaimana tetecara pengelolaan di bidang pemasaran, kegiatan tersebut juga dibarengi dengan praktik siswa dalam mempromosikan produk-produk sekolah di masyarakat. Salah satu media business center di sekolah dilakukan melalui pengadaan kantin sekolah, kantin tersebt berfungsi sebagai media siswa dalam melakukan praktik pemasaran sekaligus sebagai upaya memenuhi kebutuhan siswa disekolah. Business center memberikan dampak signifikan bagi para siswa dalam menggali dan mengasah potensi jiwa wirausaha yang mereka miliki dan memberikan pengalaman bagi mereka dalam menjalankan bisnis.

Aspek kepribadian dalam membangun jiwa-jiwa wirausaha, pengembangan kepribadian wirausaha sangat penting dalam rangka menjadi wirausahawan yang sukses dan mempunyai kepribadian unggul dan kompetitif. Terdapat 3 (tiga) tahapan yang dilakukan untuk pengembangan kepribadian wirausaha meliputi: (1) pengenalan kewirausahaan; (2) mengambil pengalaman dari wirausahawan-wirausahawan yang telah sukses; (3) melakukan praktek kewirausahaan (Wijoyo dkk, 2021).

Sedangkan aspek disiplin sangat diperlukan untuk memperoleh hasil usaha yang maksimal. Kata disiplin sendiri mengandung artian memiliki komitmen terhadap norma dan 
aturan yang berlaku. Menumbuhkan sikap disiplin dapat mendorong kemajuan usaha seorang wirausahawan. Motivasi dan semangat menjalankan usaha dapat digerakkan melalui kedisiplinan. Setiap target ataupun sasaran yang ditentukan dapat diraih ketika seorang wirausahawan senantiasa menerapkan sikap kedisiplinan (Kamiullah dkk, 2021).

Selanjutnya aspek kreativitas merupakan kemampuan atau kapasitas yang dimiliki, misalnya seorang wirausahawan dapat menghasilkan suatu produk baru yang berbeda dari sebelumnya, Pada prinsipnya, kreativitas adalah kapabilitas seorang individu, udalam menciptakan berbagai ide gagasan ataupun karya nyata yang dihasilkan memiliki orisinalitas tinggi (Asmoro, 2021). Lebih lanjut aspek motivasi merupakan motif yang muncul dari batin individu dalam rangka mewujudkan tujuan usaha. Motivasi juga dapat dikatakan sebagai keinginan maupun keinginan dalam meraih kesuksesan dan upaya menghindari kegagalan berwirausaha. Apabila wirausahawan termotivasi, mereka dapat mengambil keputusan positif dalam memuaskan hasrat mereka (Hasan, 2020).

Sementara itu aspek keberanian sangat dibutuhkan bagi setiap orang yang berprofesi sebagai wirausahawan mempunyai keinginan dan memiliki keberanian terutama dalam hal mengambil resiko dan senantiasa berusaha menjadi seorang pemenang dengan menggunakan cara yang baik. Bahkan, seorang wirausahawan yang sukses tidak takut melakukan pekerjaan dengan risiko tinggi selama wirausahawan tersebut telah menganalisa maka ia mampu mengatasi risiko tersebut. Para wirausahwan sadar bahwa sebuah kesuksesan dapat diraih dengan menghadapi resiko sebagai konsekuensi yang dihadapi dalam meraih sebuah tujuan (Sibarani dkk, 2019).

Kemudian aspek kepercayaan diri mengarahkan keyakinan dan sikap seorang individu dalam menjalankan pekerjaan ataupun suatu tugas. Dalam konteks kewirausahaan kepercayaan diri adalah sebuah keyakinan yang timbul dalam mengawali, mengerjakan serta menyelesaikan berbagai tugas tersebut. Maka dari itu, kepercayaan diri mempunyai nilai optimisme, keyakinan, ketergantungan dan individualitas. Seorang wirausahwan yang mempunyai kepercayaan diri tinggi lebih berpeluang besar untuk meraih keberhasilan dalam usahanya (Zimmerer dalam Siagian dkk, 2020).

Berdasarkan observasi awal yang dilakukan, penulis memperoleh informasi bahwa pendidikan kewirausahaan yang dilakukan siswa di Sekolah Menengah Kejuruan (SMK) Negeri 1 Posigadan Kabupaten Bolaang Mongondow Selatan merupakan proses pembelajaran yang bertujuan untuk membentuk sikap dan perilaku wirausaha ditemukan proses yang dimulai dengan melihat usaha dalam berwirausaha. Selain itu, potensi jiwa kewirausahaan siswa 
Sekolah Menengah Kejuruan (SMK) Negeri 1 Posigadan Kabupaten Bolaang Mongondow Selatan dalam berwirausaha belum diketahui secara pasti dan proses penerapannya belum berjalan dengan maksimal, sehingga keberhasilan siswa dalam berwirausaha belum optimal.

Berdasarkan uraian diatas maka dirumuskan potensi jiwa kewirausahaan dilihat dari aspek: (1) kepribadian siswa; (2) disiplin diri siswa; (3) kreatifitas siswa; (4) motivasi siswa; (5) keberanian siswa; (6) kepercayaan diri siswa di SMK Negeri 1 Posigadan Kabupaten Bolaang Mongondow Selatan.

\section{METODE PENELITIAN}

Penelitian ini menggunakan pendekatan penelitian kuantitatif dengan jenis penelitian eksplanatori. Subyek dalam penelitian ini adalah guru SMK Negeri 1 Posigadan Kabupaten Bolaang Mongondow Selatan yang berjumlah 32 orang Guru. Alasan dipilihnya guru sebagai subjek penelitian dikarenakan bahwa para guru mengetahui setiap karakteristik yang dimiliki oleh setiap peserta didik. Maka untuk dalam rangka menilai potensi jiwa kewirausahaan peserta didik di SMK Negeri 1 Posigadan di pilihlah guru sebagai subjek penelitian. Sehingga penilaian potensi jiwa kewirausahaan siswa lebih objektif dan efektif. Tehnik pengumpulan data menggunakan angket, observasi, wawancara, dan studi dokumen. Analisis data menggunakan analisis statistik sederhana (prosentase).

\section{HASIL PENELITIAN}

Setelah dilakukan analisis data terhadap aspek potensi jiwa kewirausahaan siswa di SMK Negeri 1 Posigadan: Maka hasil rekapitulasi hitungannya diuraikan sebagai berikut:

Tabel 1. Rekapitulasi Potensi Jiwa Kewirausahaan Siswa SMK N 1 Posigadan

\begin{tabular}{clccc}
\hline No & Indikator & Skor & Persentase (\%) & Kriteria \\
\hline 1 & Kepribadian & 119,20 & 74,50 & Cukup Baik \\
\hline 2 & Disiplin Diri & 118,40 & 74,00 & Cukup Baik \\
\hline 3 & Kreativitas & 115,60 & 72,25 & Cukup Baik \\
\hline 4 & Motivasi & 114,00 & 71,25 & Cukup Baik \\
\hline 5 & Keberanian & 115,80 & 72,38 & Cukup Baik \\
\hline 6 & Kepercayaan Diri & 117,80 & 73,63 & Cukup Baik \\
\hline & Rata-Rata & $\mathbf{1 1 6 . 8 0}$ & $\mathbf{7 3 , 0 0}$ & Cukup Baik \\
\hline
\end{tabular}

Sumber: Olahan data primer 2021 
Untuk lebih jelasnya nilai masing-masing indikator tersebut dapat dilihat pada diagram dibawah ini:

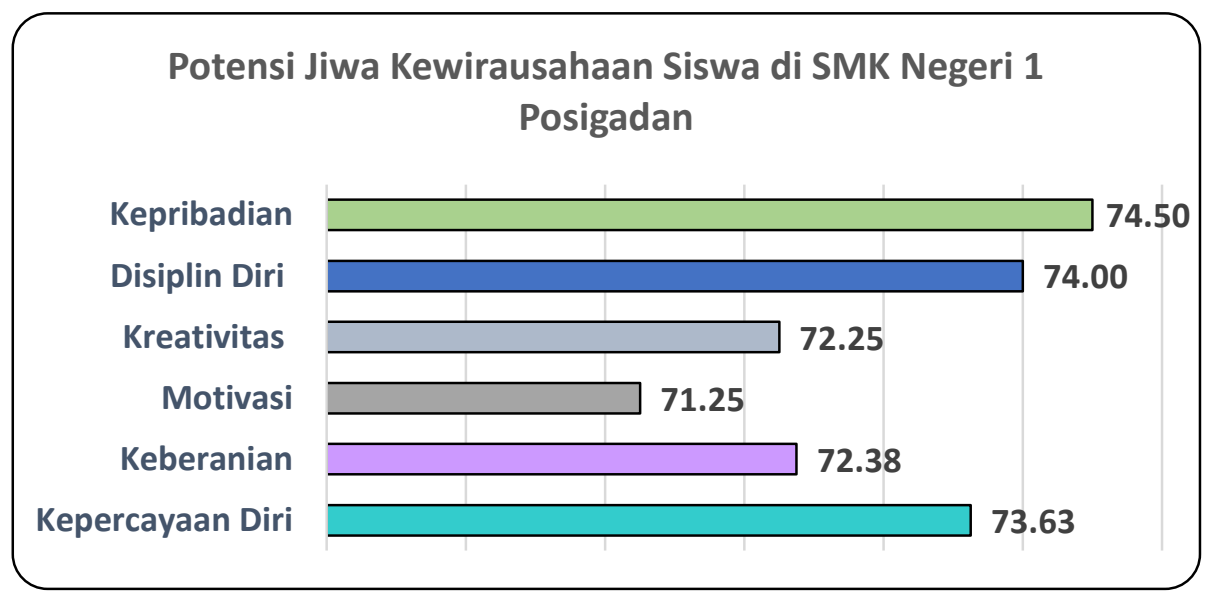

\section{Gambar 1. Diagram Keseluruhan Indikator Potensi Jiwa Kewirausahaan Siswa SMK Negeri 1 Posigadan}

Dari gambar diatas dapat dilihat dari ketiga indikator tersebut terlihat bahwa potensi jiwa kewirausahaan siswa di SMK Negeri 1 Posigadan dari aspek kepribadian memperoleh persentase $74,50 \%$, selanjutnya indikator disiplin diri memperoleh persentase $74,00 \%$, kemudian indikator kreativitas memperoleh persentase $72,25 \%$, sementara indikator motivasi memperoleh persentase sebesar 71,25, adapun indikator keberanian memperoleh persentase $72,38 \%$ dan indikator kepercayaan diri sebesar 73,63\%.

\section{PEMBAHASAN HASIL PENELITIAN}

\section{Aspek Kepribadian}

Berlandaskan dari hasil penelitian yang telah diperoleh sebelumnya mengenai potensi jiwa kewirausahaan siswa SMK Negeri 1 Posigadan dari aspek kepribadian diperoleh angka persentase sebesar 74,50\% atau dengan kata lain berada pada kategori cukup baik. Artinya para peserta siswa dan siswi yang ada di SMK Negeri 1 Posigadan mempunyai karakteristik kepribadian yang dapat menunjang mereka menjadi seorang entrepreneur.

Hal ini sesuai dengan yang dikemukakan oleh Suryana dan Bayu (dalam Roskina, 2017) bahwa sikap kerja keras merupakan landasan awal dalam rangka meraih kesuksesan, maka dari itu setiap wirausahwan wajib untuk bekerja keras dalam memprakarsai ataupun merintis usahanya menuju pintu kesuksesan. Demikian pula temuan Bygrave, Alma dalam penelitian Arifin (2015) bahwa dalam penelitiannya yang membentuk keinginan seorang individu menjadi seorang entrepreneur dipengaruhi beragam aspek-aspek responsif pribadi yang mempengaruhi seseorang tersebut, yang berkaitan dengan faktor-faktor kepribadian tersebut 
meluputi: hubungan sosial, berkaitan dengan hubungan keluarga serfta menyangkut hubungan dengan lingkungan sekitarnya (environmental).

Dari hasil penelitian peneliti dan didukung dengan hasil penelitian sebelumnya maka dapat dikatakan bahwa menunukkan bahwa potensi wirausaha seorang peserta didik membutuhkan kepribadian yang kuat, mempunyai inisiatif tinggi, bersikap jujur dan tanggung jawab, mengutamakan kualitas produk yang dihasilkan serta mempu menjalin relasi dengan berbagai pihak sehingga dengan berbekal dengan kepribadian tersebut para peserta didik dapat sukses menjalankan usahanya dimasa mendatang.

\section{Aspek Disiplin Diri}

Berlandaskan dari hasil penelitian yang telah diperoleh sebelumnya mengenai potensi jiwa kewirausahaan siswa SMK Negeri 1 Posigadan dari aspek disiplin diri diperoleh angka persentase sebesar 74,00\% atau dengan kata lain berada pada kategori cukup baik. Artinya para peserta siswa dan siswi yang ada di SMK Negeri 1 Posigadan memiliki sikap disiplin sebagai bekal mereka ketika menjadi seorang wirausahawan, sebab melalui sikap disiplin mereka senantiasa memiliki komitmen terhadap tugas dan pekerjaannya dalam menjalankan usaha.

Roskina dan Sumo (2017) dalam jurnal penelitiannya juga menegaskan bahwa dalam rangka melahirkan spirit terhadap kewirausahaan serta menumbuhkan wirausahawan muda baru, maka pemerintah mengeluarkan instruksi presiden Nomor 4 tahun 1995 tentang gerakan nasional memasyarakatkan dan membudayakan kewirausahaan. Dengan gerakan tersebut bangsa memiliki harapan yang besar akan karakter kewirausahaan menjadi sebuah kesatuan dari etos kerja warga negara kesatuan republik Indonesia, sehingga dapat menghasilkan wirausahawan-wirausahawan baru, handal, tangguh, dan mandiri.

Dari hasil penelitian peneliti dan didukung dengan hasil penelitian sebelumnya maka dapat dikatakan bahwa disiplin diri sangat penting untuk dimiliki siswa. Sikap disiplin dapat membentuk jiwa kewirausahaan siswa menjadi seseorang senantiasa memiliki komitmen terhadap tugas-tugas yang diembannya, disiplin terhadap waktu dan target pekerjaan serta senantiasa memegang teguh norma dan nilai-nilai yang berlaku. Sehingga melalui sikap disiplin tersebut para siswa dapat meraih cita - cita yang diharapkannya terutama dalam menjalankan sebuah wirausaha.

\section{Aspek Kreativitas}

Berlandaskan dari hasil penelitian yang telah diperoleh sebelumnya mengenai potensi jiwa kewirausahaan siswa SMK Negeri 1 Posigadan dari aspek kreativitas diperoleh angka persentase sebesar 72,25\% atau dengan kata lain berada pada kategori cukup baik. Artinya para 
peserta siswa dan siswi yang ada di SMK Negeri 1 Posigadan memiliki kemampuan dalam menuangkan berbagai ide dan gagasan melalui berfikir kreatif dalam menciptakan sesuatu.

Sebagaimana Chandra (dalam penelitian Roskina dan Sumo, 2017) mengungkapkan bahwa seorang wirausaha merupakan pribadi yang mempunyai jiwa dan kepabilitas tertentu dalam melakukan sebuah kreasi dan inovasi dalam menciptakan sesuatu yang baru dan berbeda. Kemampuan berkreasi dan berinovasi dapat terefleksi dari kemampuan dan keinginannya untuk merintis usaha baru, tidak takut mencoba, mengerjakan sesuatu yang orisinil, mampu mencari peluang, mampu dan berani mengambil resiko, berani gagal, berani sukses, dan mampu mengembangkan ide dan merancang sumber daya menjadi sebuah hal yang berkualitas.

Demikian pula penelitian Diandra (2019) menunjukkan bahwa sebuah ide yang unik hanya bisa dimunculkan dari sebuah imajinasi yang kemudian di aktualisasika dalam kehidupan nyata. Kreatifitas pada kapasitas daya imajinasi seseorang adalah dengan membayangkan sebuah gagasan kemudian dijadikan kenyataan. Kreativitas seorang wirausahawan dapat dilihat dari bagaimana ia menghasilkan berbagai produk unik yang berdaya saing tinggi. Keunikan tersebut dalam artian sebagai sebuah model, corak, warna, bentuk, dan sebagainya dan bermuara pada satu titik tentang bagaimana menghasilkan sebuah produk baru maupun produk lama yang dirubah menjadi baru lagi.

Dari hasil penelitian peneliti dan didukung dengan hasil penelitian sebelumnya menunjukkan bahwa aspek kreativitas memiliki peranan penting dalam dunia kewirausahaan. Melalui kreativitas para peserta didik mampu mengembangkan imajinasinya menjadi sebuah kenyataan dengan menciptakan berbagai ide-ide dan menghasilkan berbagai karya-karya inovatif yang baru dan berbeda dengan produk-produk lainnya. Dengan kreativitas seseorang dapat meraih kesuksesan dalam usahanya sebab dengan berfikir kreatif seseorang dapat melihat berbagai peluang usaha dan dapat bersaing dipasaran.

\section{Aspek Motivasi}

Berlandaskan dari hasil penelitian yang telah diperoleh sebelumnya mengenai potensi jiwa kewirausahaan siswa SMK Negeri 1 Posigadan dari aspek motivasi diperoleh angka persentase sebesar $71,25 \%$ atau dengan kata lain berada pada kategori cukup baik. Artinya para peserta siswa dan siswi yang ada di SMK Negeri 1 Posigadan mempunyai keinginan ataupun dorongan dari dalam diri untuk melakukan kegiatan berwirausaha.

Demikian pula hasil penelitian Bayu (2021: 60) bahwa variabel pendidikan kewirausahaan $\left(\mathrm{X}_{1}\right)$ dan variabel motivasi $\left(\mathrm{X}_{2}\right)$ berpengaruh signifikan secara bersama- 
sama atau simultan terhadap minat usaha (Y) pada mahasiswa Program Studi Ekonomi Hindu Sekolah Tinggi Agama Hindu Negeri Gde Pudja Mataram, yang didasarkan pada F hitung sebesar 25,953, sehingga $\mathrm{F}$ hitung $>\mathrm{F}$ tabel $(25,953>3,10)$, serta nilai signifikan sebesar 0,000 yang lebih kecil dari 0,5. Berdasarkan hipotesis 2 diperoleh hasil variabel pendidikan kewirausahaan (X1) sebesar 0,000 dan lebih kecil dari 0,05, hal ini membuktikan pendidikan kewirausahaan berpengaruh signifikan terhadap minat usaha (Y).

Hasil temuan penelitian Dewi (2013) menunjukkan bahwa, terdapat 2 (dua) variabel yang berpengaruh terhadap motivasi berwirausaha yang meliputi pengalaman pendidikan kewirausahaan dan keterampilan kejuruan. Baik secara parsial, ataupun secara simultan, kedua variabel tersebut memiliki pengaruh yang positif bagi motivasi berwirausaha peserta didik. Hal tersebut memberikan gambaran bahwa, semakin besar pengalaman pendidikan kewirausahaan dan keterampilan kejuruan yang dimiliki maka motivasi berwirausaha peserta didik juga semakin besar pula.

Dari hasil penelitian peneliti dan didukung dengan hasil penelitian sebelumnya menunjukkan bahwa aspek motivasi memiliki kedudukan penting dalam menggali potensi jiwa wirausaha para siswa. Terlebih lagi, ketika seorang siswa ingin menjadi seorang entrepreneur muda yang sukses dan berhasil harus memiliki motivasi yang tinggi yang ditunjukkan dengan memiliki tekad yang kuat dan bekerja keras, patang menyerah, mengembangkan berbagai ideide kreatif dan senantiasa mendorong diri pribadi untuk dapat menghasilkan sesuatu produkproduk yang bermanfaat bagi kehidupan masyarakat serta selalu tekun dan berdoa bahwa segala sesuatu usaha yang dijalankan dapat berdampak positif.

\section{Aspek Keberanian}

Berlandaskan dari hasil penelitian yang telah diperoleh sebelumnya mengenai potensi jiwa kewirausahaan siswa SMK Negeri 1 Posigadan dari aspek keberanian diperoleh angka persentase sebesar 72,38\% atau dengan kata lain berada pada kategori cukup baik. Artinya para peserta siswa dan siswi yang ada di SMK Negeri 1 Posigadan mempunyai keberanian dalam melangkah maju sebagai modal awal dalam menjadi seorang wirausahawan.

Wulandari dan Deliabilda (2020) dalam penelitiannya menunjukkan bahwa keberanian seorang wirausahawan dalam mengambil keputusan yang mengandung risiko menjadi bekal untuk mengembangkan sebuah usaha. Dibutuhkan rancangan persiapan dalam memperhitungkan perubahan lingkungan di masa mendatang agar dapat membuat keputusan yang baik dalam guna kemajuan sebuah usaha. Karakter percaya diri dan berani mengambil risiko memiliki kedudukan yang tinggi dibandingkan dengan karakter lainnya seperti 
kreativitas, inovasi, kepemimpinan, dan orientasi. Dalam mengambil sebuah risiko sangat diperlukan kepercayaan diri yang mendalam. Ciri utama yang dapat membedakan seorang pengusaha dengan karyawan adalah dengan keberanian mengambil resiko.

Roskina (2017) juga mengatakan bahwa sikap inovatif, tercermin dari perilaku yang berani untuk melakukan sesuatu yang terbilang berbeda dan baru. Pengembangan sebuah unit produksi memerlukan kreativitas, karena unit produksi tidak hanya bergantung pada peluang yang sudah ada, akan tetapi harus menghasilkan berbagai peluang yang baru yang dapat diaktualisasikan untuk berjalannya sebuah unit produksi sekolah. Selain itu, keberanian dalam mengeluarkan berbagai inovasi dan terobosan yang berbeda, dengan biaya yang minim maupun berfokus pada suatu jenis produk maupun layanan memerlukan sebuah kreativitas tersendiri.

Dari hasil penelitian peneliti dan didukung dengan hasil penelitian sebelumnya menunjukkan bahwa aspek keberanian diri adalah karakter yang harus dimiliki oleh setiap orang, terlebih lagi seorang siswa yang ingin menjadi entrepreneur muda. Dengan keberanian seseorang wirausahawan dapat berani mengambil resiko, berani, tegas dalam memutuskan sesuatu, berani untuk bersaing. Sehingga dengan keberanian yang dimilikinya mereka dapat memutuskan berbagai keputusan yang tepat yang dapat memajukan usahanya.

\section{Aspek Kepercayaan Diri}

Berlandaskan dari hasil penelitian yang telah diperoleh sebelumnya mengenai potensi jiwa kewirausahaan siswa SMK Negeri 1 Posigadan dari aspek kepercayaan diri diperoleh angka persentase sebesar 73,63\% atau dengan kata lain berada pada kategori cukup baik. Artinya para peserta siswa dan siswi yang ada di SMK Negeri 1 Posigadan mempunyai sikap yakin akan kemampuan diri sendiri terhadap pencapaian, keinginan, dan harapannya. Serta pribadi yang tidak takut gagal, tidak mudah putus asa, dan akan selalu merasa bahwa dirinya mampu serta tidak ragu-ragu dalam memecahkan masalah.

Hasil diatas juga sesuai dengan penelitian Fithriyana (2017) bahwa dalam membangun kemandirian siswa dibutuhkan metode yang tepat, yang mana salah satunya adalah dengan pendidikan kewirausahaan. Melalui pendidikan kewirausahaan peserta didik dapat memiliki karakter kemandirian, terutama kemandirian pada sektor ekonomi sehingga dapat membentuk mereka menjadi seorang enterpreneurs yang sukses. Pendidikan adalah pintu gerbang untuk membentuk generasi penerus bangsa yang unggul, tangguh, ulet baik secara pribadi maupun kelompok. Pada akhirnya pendidikan kewirausahaan merupakan salah satu alternatif dalam mengembangkan segala potensi generasi muda melalui pembelajaran di lembaga pendidikan. 
Dari hasil penelitian peneliti dan didukung dengan hasil penelitian sebelumnya menunjukkan bahwa aspek kepercayaan diri adalah potensi jiwa wirausaha yang paling penting. Sebab kepercayaan diri adalah modal utama dan karakter utama yang harus dimiliki seorang siswa. Karena dengan kepercayaan diri seseorang yakin akan kemampuan diri sendiri terhadap pencapaian keinginan dan harapannya. Percaya diri yang kuat akan mampu memotivasi untuk lebih maju membiasakan menyelesaikan masalah sendiri, tanpa bergantung kepada orang lain.

\section{SIMPULAN}

Berdasarkan hasil penelitian maka dapat disimpulkan bahwa potensi jiwa kewirausahaan siswa SMK Negeri 1 Posigadan Kabupaten Bolaang Mongondow Selatan dilihat dari aspek: (1) kepribadian berada pada kategori cukup baik. Peserta didik memiliki kepribadian yang baik, memiliki inisiatif, mengedepankan kerja keras, mengutamakan kejujuran dan bertanggung jawab; (2) disiplin diri berada pada kategori cukup baik. Peserta didik memiliki komitmen yang tinggi dalam mengerjakan berbagai tugas yang diberikan, dengan mengedepankan disiplin waktu, memegang teguh prinsip, nilai dan norma yang belaku disertai dengan etos kerja yang tinggi; (3) kreativitas berada pada kategori cukup baik. Peserta didik senantiasa berusaha memunculkan ide-ide gagasan kreatif dan inovatif, mampu beradaptasi dengan teknologi dan selalu memiliki rasa keingitahuan yang tinggi terhadap dunia usaha; (4) motivasi berada pada kategori cukup baik Peserta didik mempunyai keinginan dan dorongan dari dalam diri untuk maju dan berkembang, selalu berusaha meningkatkan kompetensi dan skill; (5) keberanian berada pada kategori cukup baik. Sebagian peserta didik memiliki keberanian dalam menjalankan usaha, berani untuk berinovasi dan memiliki keberanian untuk bersaing serta menyukai berbagai hal-hal yang penuh dengan tantangan; (6) kepercayaan diri berada pada kategori cukup baik. Sebagian peserta didik memiliki rasa percaya diri dan yakin akan kemampuannya dalam melakukan sebuah usaha dan berusaha untuk mandiri dan tidak bergantung pada orang lain dan memiliki jiwa optimis dan pantang menyerah dalam menghadapi sesuatu.

\section{REFERENSI}

Arifin S. 2015. Pengaruh Faktor Personal, Sociological, dan Environmental Terhadap Minat Berwirausaha Warga Desa Watesumpak Kecamatan Trowulan Kabupaten Mojokerto. Jurnal Pendidikan Administrasi Perkantoran (JPAP). 3 (1), 1-15. 
Asmoro S., W. 2021. Produk Kreatif dan Kewirausahaan SMK/MAK Kelas XI. Program Keahlian Teknik Komputer dan Informatika. Kompetensi Keahlian Multimedia. Yogyakarta: Andi.

Wijaya, B. 2021. Pengaruh Pendidikan Kewirausahaan Dan Motivasi Terhadap Minat Berwirausaha Mahasiswa. Jambura Economic Education Journal. 3 (2), 52-61.

Dewi A., V. 2013. Pengaruh Pengalaman Pendidikan Kewirausahaan Dan Keterampilan Kejuruan Terhadap Motivasi Berwirausaha Siswa. Jurnal Pendidikan Vokasi. 3 (2), 163-177.

Dhanupoyo dan Roskina. 2015. Pembinaan Kompetensi Kewirausahaan Siswa SMK Negeri 1 Limboto Kabupaten Gorontalo. Jurnal Manajemen Pendidikan. 3 (2), 107-120.

Diandra D. 2019. Menggali Potensi Kreatifitas Dalam Kewirausahaan. Prosiding SNasPPM. 3 (2), 80-85.

Fithriyana R. 2017. Membentuk Kemandirian Siswa Sekolah Dasar Melalui Pendidikan Kewirausahaan. Jurnal Basicedu. 3 (2), 100-105.

Hasan M., 2020. Literasi dan Perilaku Ekonomi: Transfer Pengetahuan Kewirausahaan dalam Perspektif Pendidikan Ekonomi Informal. Bandung: Media Sains Indonesia.

Kamiullah A., Z., dkk. 2021. Kewirausahaan dan Bisnis. Medan: Yayasan Kita Menulis.

Lukman, H. S. 2015. Mengembangkan Potensi Wirausaha Siswa SMK 2 Muhammadiyah Melalui Pengelolaan Business Center. Jurnal Surya: Seri Pengabdian kepada Masyarakat. 1 (1), 21-27.

Mubarok Z., Tanjung H., dan Tamam A., M. 2017. Konsep Pendidikan Wirausaha Dan Kemandirian Bagi Anak Panti Asuhan. Jurnal Ta'dibuna. 6 (1), 96-117.

Roskina dan Sumo. 2017. Transformasi Nilai-Nilai Kewirausahaan Pada Siswa SMK. Jurnal Manajemen dan Supervisi Pendidikan. 2 (1), 9-15.

Roskina. 2017. Kewirausahaan Kepala Sekolah. Yogyakarta: Zahir Publishing

Sibarani C., G., dkk. 2019. Dasar-Dasar Kewirausahaan. Medan: Yayasan Kita Menulis.

Sutianah, C. 2020. Pengembangan Karakter Kebangsaan dan Karakter Wirausaha Melalui Implementasi Model Pembelajaran Teaching Factory 6 Langkah (TF-6M). Pasuruan: Qiara Media.

Wijoyo H., dkk. 2021. Dosen Inovatif Era New Normal. Solok: Insan Cendekia Mandiri.

Wulandari A., dan Deliabilda S., A. 2020. Keberanian Mengambil Risiko Bisnis pada Mahasiswa Ekonomi dan Bisnis. Jurnal Pengembangan Wiraswasta. 22 (3), 217-227. 